\title{
THE POWER OF LOVING HUMANE CARE IN NURSING ${ }^{1}$
}

\author{
Digna Escobar Rivero ${ }^{1}$ \\ Alacoque Lorenzini Erdmann ${ }^{2}$
}

Escobar Rivero D, Erdmann AL. The power of loving humane care in nursing. Rev Latino-am Enfermagem 2007 julho-agosto; 15(4):618-25.

This study aimed to develop an approach about the power of humane care within the concept of nursing through the building of a theoretical structure. Spiegelberg's methodology was used to seek the meaning of the power of humane care for new nurses and for patients. The resulting theoretical structure is based on Parker's theory of power, Patterson and Zderad's humane care, Watson's theories and Larrañaga's concept of love. The elements of this structure are: the nurse, the ill or healthy person, the environment and nursing, all bound by an affectionate humane care. The final reflection was that all of them are included within the technicalscientific paradigm of modernity and that the patients hope to be care for by humane nurses.

DESCRIPTORS: power (psychology); love; nursing

\section{EL PODER DEL CUIDADO HUMANO AMOROSO EN LA ENFERMERÍA}

Este estudio tuvo como propósito desarrollar una aproximación sobre el poder del cuidado humano en la concepción de Enfermería a través de la construcción de una estructura teórica. Se utilizó la propuesta metodológica de Spiegelberg, buscando el significado que tiene el poder y el cuidado humano para nueve enfermeras y dos enfermos. La estructura teórica resultante se orienta a como la enfermería puede lograr poder a través del ejercicio del cuidado humano basado en el amor, apoyada en las teorías del poder de Parker, de cuidado humano de Paterson y Zderad, Watson y la concepción del amor de Larrañaga. Los elementos de la estructura son la enfermera, la persona sana o enferma, el ambiente y la enfermería, unidos en el cuidado humano amoroso. La reflexión final indica que las enfermeras están ubicadas dentro del paradigma tecno-científico de la modernidad, mientras que los enfermos esperan ser cuidados por enfermeras humanas.

DESCRIPTORES: poder (psicología); amor; enfermería

\section{O PODER DO CUIDADO HUMANO AMOROSO NA ENFERMAGEM}

Este estudo teve como propósito desenvolver uma aproximação sobre o poder do cuidado humano na concepção da Enfermagem através da construção de uma estrutura teórica. Foi utilizada a proposta metodológica de Spiegelberg buscando o significado que tem o poder e o cuidado humano para enfermeiras novas e para os enfermos. A estrutura teórica resultante se orienta em como a enfermeira pode conseguir poder através do exercício do cuidado humano baseado no amor, apoiada nas teorias do poder de Parker, de cuidado humano de Paterson y Zderad, Watson e a concepção de amor de Larrañaga. Os elementos da estrutura são: a enfermeira, a pessoa sadia ou doente, o ambiente e a enfermeira, unidos pelo cuidado humano amoroso. A reflexão final indica que as enfermeiras estão inseridas dentro do paradigma técnico-científico da modernidade e que os pacientes esperam ser cuidados por enfermeiras humanas.

DESCRITORES: poder (psicologia); amor; enfermagem

${ }^{1}$ Paper extracted from Doctoral Dissertation; ${ }^{2} \mathrm{PhD}$ in Nursing, Full Professor, University of Carabobo School of Nursing, Venezuela; ${ }^{3}$ PhD in Nursing Philosophy, CNPq Researcher, Full Professor, Santa Catarina Federal University Nursing Department, Brazil, e-mail: alacoque@newsite.com.br 


\section{INTRODUCTION}

$\boldsymbol{I}_{\mathrm{n}}$ Venezuela, nursing is facing a moment of transition regarding its consolidation as a profession. This is evidenced when studying central aspects like power, which emanates from the essence of its practice: offering humane care to individuals, families and healthy or ill groups. Power is the strength that triggers the changes demanded by society. Humane care, due to the debilitation of man's transcendental values, is present in the current century, marked by dehumanization among human groups.

The researcher's large experience as a nurse at public health centers, in outpatient and hospital care, in addition to performing health care, association, administrative and faculty tasks has provided her with a view of the reality regarding Venezuelan nursing profession. Despite its irreplaceable social role in preserving human life, nursing does not receive appropriate treatment from society. This fact aroused the idea to review a few factors associated with this reality.

In this quest, very important empirical evidence was found, such as the lack of a Professional Practice Law and the fact that there are many academic levels, but without occupational profiles describing the tasks for each level. This causes confusion, since there is no role definition. Another evidence of the studied phenomenon is the encapsulated nursing work, with a monodisciplinary approach to health care. The historically prevalent leadership of very small groups was also observed, which are responsible for the profession's advancement, although this goes by unnoticed by the patient community. One of the most significant evidences guiding the study was the lack of the nursing profession in the political structure of the Venezuelan Health Ministry, with a consequent absence of participation in high-level decision making.

Through qualitative research and using the method proposed by Spiegelberg ${ }^{(1)}$, the phenomenon "power of humane care" could be outlined, delivered by nurses, in the search for the multiple perspectives of the studied nurses, patients, and the researcher's points of view. This method consists of six phases: outlining the phenomenon, searching for the multiple perspectives, searching for the essence and structure, building the meaning, suspension of judgments, and interpreting the phenomenon. This permitted searching the meaning that nurses assign to power and humane care.

\section{FOUNDATIONS OF THE STUDY PHENOMENON}

Power has been extensively studied in sociology and administration. Classic reports like those by Parsons, Max Weber, Giner and others are guided by the conception that power is a key element in social relationships, in which one person's desire is imposed over others', and over their resistance, regardless of that imposition being fair or not. This has been referred to as "power over", as the capacity of exerting influence, adopting an expected behavior.

Power is an ability of individuals or groups make their own interests or motivations prevail, despite the resistance they may face ${ }^{(2-3)}$. Power is also a social fact in which some give orders and others obey. Human groups cannot exist without power. When questioning about power in nursing, it is observed that this issue has been studied in the United States since the 1960's. Power development in nursing has been delayed by characteristics specific to the profession, to the place where nurses work and by their not knowing that it is a positive strength that can be used as an instrument to make the expected social changes. After reviewing some traditional conceptions of power, it was observed that they had the common denominator putting yourself above others, dominating, being or arriving first, in which there is no simultaneous place for two, regardless of whether the prevalence of one over the other is useful. This conception of power over is not the power that nurses could use in their professional relationships with healthy or ill individuals. Those relationships should be horizontal and intersubjective, in which they share the goal of improving the health situation: nurses with their care delivery goal, and healthy or ill individuals as care receivers.

Previewing this encounter in an environment consisting of understanding, respect and transparency recalls Parker's ${ }^{(4)}$ theory, which defends the innovative 
idea of power with, which is immersed in people's lives and should be sought with, for and from people. Moreover, it should be constructed by integrating desires, efforts, and interests, so as to facilitate power with and impede domination or power over. It emphasizes that power with means the simple ability to make things happen, developed in an active and participative way; collectively, not coercively. The author of this study directs power in an integrative social action, which results from natural collaborative work with other people, and not as an imposition of desires.

This type of power is in harmony with present times, since people currently reject being directed with domination. Rather, they expect to be taken into consideration and be treated as human beings. Moreover, the tendency now is for horizontal relationships, which do not exist with coercive domination, power over. This is demanded by sociopolitical, cultural and economic determinants. Nursing, through the quest to provide society with better support, also follows the power with paradigm in establishing actions to sustain humane care.

The conception of love has been considerably approached, and this study discusses forms of using it in nursing. By practicing loving humane care, nursing can acquire the necessary power to irradiate that love in health institutions and obtain social legitimacy in Venezuela.

Therefore, love is understood as "the ability to feel concern, responsibility, respect, and understanding toward others" ${ }^{(5)}$ and, complementarily, love is finding and recognizing others considering their subjectivity, it is wanting others as subjects ${ }^{(6)}$, it is to affirm others and respond to their call. In addition, authentic love is unconditional, uninterested, and implies being loyal to others. Hence, it is assumed that every man needs to love and be loved in a natural way. Thus, love-based humane care in nursing would mean the authentic expression of its essence and the pathway to transcendence ${ }^{(7)}$.

Regarding humane care support, the propositions presented in Paterson and Zderad's humanistic nursing theory are considered, which states that nursing means "a special human encounter as the answer to a noticed need, associated with health quality - illness, of the human condition. Nursing seeks to care for wellbeing and improvement, through an intentional encounter, in which there is a call and an intentional answer, as a sort of dialogue ${ }^{(8)}$. Thus, care factors from Watson's theory are also incorporated, which highlights that love, lovability and equanimity should be practiced within the context of conscientious care. Transpersonal care is understood as thorough human-human connection. It means that nurses enter others' space and are able to detect their condition; they understand others' to the extent that when giving them an answer, nurses feel relief from those feelings, thoughts, and tensions. The ideas regarding the aforementioned theories are presented in the final section of the present research about the power of loving humane care.

\section{THE PATHWAY}

A qualitative research ${ }^{(9)}$ was performed, using the phenomenological-hermeneutic approach. Data collection was performed through the focus interview technique. Husserl's ${ }^{(10)}$ ideas were used, which consider phenomenology as the method that attempts to understand man's world through an intellectual view, based on intuition over the fact. Knowledge is acquired by trying to see things from other peoples' perspectives, describing, understanding, interpreting. In this case, the meaning of power for each keyinformant was studied, considering his/her own experiences.

Spiegelberg's ${ }^{(1)}$ method proposal permitted describing the phenomenon "power of humane care" provided by nurses, with a view to obtaining the multiple perspectives built by patients' and nurses' statements and considering the researcher's perspective as well. The information was organized according to internal relationships, in order to find the essence and the structure. Meaning was determined by a thorough analysis of the structures, until the total phenomenon could be visualized. In the judgment suspension phase, the investigator had a clear idea of the informants' point of view, and, finally, interpreted the phenomenon and assigned meanings, taking the existing theories into 
consideration.

The information was organized by means of the focus interview technique according to Merton, who states that it is a form of non-directed interview addressing a certain focus. It is an experience, a situation, an action toward a concrete individual, previously characterized for having had that experience $^{(11)}$.

The present study was performed in Valencia, Carabobo state, an industrial region in Venezuela and a model city concerning Health Sector Decentralization.

The key-informants were nine high-level nurses: two managers of the most important private health centers, one outpatient clinic head nurse, two supervisors from the public and private sector, two direct-care qualified nurses from outpatient clinics and hospitals, one experienced faculty member, and one experienced association member, administratorfaculty member. Interviews were guided by two central aspects: the meanings of power and of humane care power. Guiding questions were the following: what does power mean to nurses? What are the characteristics of nursing practice? What type of power have nurses used in their daily work? Are nurses aware of the power in human care? Do nurses believe that humane care gives power?

Nurses were asked to describe what they are like and what was expected of them.

Interviews concerning the meanings of power and humane care were performed by the researcher. A photo camera and a tape recorder were used to record the information, with previous authorization from the informants, and guaranteeing the confidential character of the information they provided. Gemstone names were used as fictitious names. The eleven interviews were recorded, compiled, and integrally and faithfully transcribed. Next, they were analyzed according to Spielberg's method. Intersection matrices were determined, first by excerpts, and then by the intersections of the three excerpts (Table 1), which composed the study results to be interpreted, recommended and used to elaborate the theoretical structure.

Table 1 - Intersection matrix of all excerpts

\begin{tabular}{|c|c|c|c|c|}
\hline Categories & Participants & External agents & Investigator & Intersections \\
\hline \multirow[t]{8}{*}{$\begin{array}{l}\text { Meaning of } \\
\text { power }\end{array}$} & - Making decisions & $\begin{array}{l}\text { - Nurses provide treatments, cures } \\
\text { and medication }\end{array}$ & $\begin{array}{l}\text { - Ability to establish } \\
\text { intersubjective relationships with } \\
\text { people or groups }\end{array}$ & - Power is influence \\
\hline & - Solving problems & - They are bothered by patients & - Seeks consensus & $\begin{array}{l}\text { - Power is interpersonal } \\
\text { relationship }\end{array}$ \\
\hline & - Assign jobs & $\begin{array}{l}\text { - Bathe ill people who are incapable } \\
\text { of doing it themselves }\end{array}$ & - Unifies ideas & - It is communication \\
\hline & - Authority relationship & $\begin{array}{l}\text { - Do not like to see relatives in the } \\
\text { room }\end{array}$ & $\begin{array}{l}\text { - Sets an environment of respect, } \\
\text { safety, responsibility, concern } \\
\text { toward others }\end{array}$ & \\
\hline & - Domination and dependence & - Rush in doing things & - Mutual influence & \\
\hline & - Job performance & - Are usually in a bad-mood & - Open toward others & \\
\hline & $\begin{array}{l}\text { - Demands academic and technical } \\
\text { preparation or experience }\end{array}$ & - Do not have time for everyone & - Union strength in diversity & \\
\hline & $\begin{array}{l}\text { - Influence and relationship, } \\
\text { communication skills }\end{array}$ & $\begin{array}{l}\text { - Sometimes are not punctual in } \\
\text { treatments }\end{array}$ & & \\
\hline \multirow{6}{*}{$\begin{array}{l}\text { Power of } \\
\text { humane } \\
\text { care }\end{array}$} & - Power depends on the job position & $\begin{array}{l}\text { - They should be loveable, thoughtful } \\
\text { and caring }\end{array}$ & - Humane care generates power & $\begin{array}{l}\text { - Working for the benefit } \\
\text { of others }\end{array}$ \\
\hline & $\begin{array}{l}\text { - It means taking responsibility for } \\
\text { the position }\end{array}$ & $\begin{array}{l}\text { - They should follow treatments at the } \\
\text { determined time }\end{array}$ & $\begin{array}{l}\text { - It is influence based on love for } \\
\text { others }\end{array}$ & - It means serving others \\
\hline & - It is working for the benefit of others & $\begin{array}{l}\text { - They should be sympathetic, } \\
\text { considerate, and understanding. }\end{array}$ & $\begin{array}{l}\text { - It is a interpersonal relationship } \\
\text { that values and considers others } \\
\text { as people }\end{array}$ & \\
\hline & $\begin{array}{l}\text { - It is sharing ideas and work with } \\
\text { colleagues }\end{array}$ & & - Mutual benefit & \\
\hline & $\begin{array}{l}\text { - It is having the knowledge } \\
\text { concerning the job }\end{array}$ & & & \\
\hline & $\begin{array}{l}\text { - It is serving others, helping or } \\
\text { assisting }\end{array}$ & & & \\
\hline
\end{tabular}


In the search for essence and structure,

Table 2 presents the meaning units obtained in the analysis of the information regarding nurses' perspectives.

Table 2 - Meanings stated by nurse informants, identified with fictitious names

Informants Meanings of power

Meanings of humane care power

The chance of making decisions, seeing and getting where decisions are made; nurses with power report superiors about their subalterns'

Esmerald work; take responsibility for their right and wrong doings; corrects people; doing what the job position demands is good for me; solves community problems; takes responsibilities concerning the job; responds for what they do or do not do.

Without power there is nothing we can do; as a nurse I have the power that means being at others' service; it is being with people as another person in the group; those with more power must be more servant; power is not exclusively for one person but it is to be distributed among others to do good; each person in their position has power and

Pearl hierarchy and provides service with respect, courtesy, good treatment, with a nice face and to benefit health; it demands high human condition, implies on listening to people, finding solutions to patients' problems; to assume that physical life, human life, and spiritual, affective, emotional life, is in the nurses' hands; power requires surrendering and dedication; academic preparation is fundamental but human condition is more.

You get power by giving power; it is authority transmitted by the influence that one has through role modeling; it is authority in performance; power is competence to negotiate and to communicate with people in the environment and organization; it is negotiation skill, communication; ability to communicate with the staff transparently unti the message is authentically transmitted; giving the opportunity for people to participate; by speaking and expressing oneself, power is obtained from people and increases.

It is doing things, the job, the task; working with energy, developing abilities and skills; it generates fear to take it, to face responsibilities; it demands capacity, preparation and knowledge; being aware of nursing having the human being to be assisted; assisting patients with will and desire to do that; one who makes decisions and communicates.

It can be used both negatively and positively; it is authority, autonomy, and leadership; it is given by a superior; it serves for getting many things; it is the responsibility of a job position, it is given by the position;

Brilliant II it is a fortress that the individual has to make and order; it serves to develop projects, participate in changes, develop plans; the capacity to establish relations with others; the capacity to communicate with others

It is having knowledge and information; it is having domain over others, over people, over the situation; it is longing for people to obey you,

Safire respect your decisions, and follow your ideas, do what you say; powe is associated with the position; it is practical ability; having leadership skills and transmitting what you know so others can improve; being perseverant, tenacious, and bold.

Having influence over others in solving conflicts, reaching goals, nurses' participation in making decisions within their hierarchy level; it is interpersonal; it is a dependence relationship; competency at the job, leadership skills, having respect and loyalty from subalterns, respecting norms and rules, taking goals and responsibilities.

Ability of doing, being, and obtaining; making people believe in me and in what I believe in; reaching one's or others' goals by influence; it does not depend on the position but on the capacity of influence over others. You give yourself the power and other ratify it; it consists of responsibility, empathy toward patients, being lovable, respectful and caring, sharing your knowledge with those who need it; to concern about your colleagues and their professional development.

Power is based on technical operational abilities, on knowledge; it is effective when people with power meet the organization's needs; it is the capacity to influence others; it depends on how you work in your

Amethyst position; the higher the position, the higher the power; it requires team work; it is the capacity to interact with others; it requires academic education according to the position; the ability to make decisions; to inspire confidence and credibility in your colleagues.
The power that the job position description gives me and I follow it by the letter; I make decisions that are my responsibility as a nurse; I work for the community's benefit; I have high professional commitment, which means working by vocation and it means working hard in nursing, that is how you reach transcendence.

Service power: the responsibility of the position is associated with the service to others; power as an enormous task of surrendering to others, but not being wage-driven because wage-driven power corrupts us.

Power of negotiation, communication; share and discuss ideas to reach agreements, based on the principles of honesty, fairness, equity, and tolerance; to have clear goals, responsibility; my relationship with the patient is very important. All my propositions aim at benefiting patients, the institution, and nursing, and this has influenced my long experience as administrator of the nursing department and always dedicate time to be in the rooms with the patients.

It is interaction or communication with others; power of knowledge, of my patients' attention, their satisfaction; helping people with direct-care tasks; being punctual, sharing, and focusing on patient care.

I have an equal relation with my colleagues, respecting their role; making people participate in making decisions; listening before acting, respecting their decisions; permanent harmonic treatment; avoiding disagreements.

Power in caring, in teaching others so they can be good nurses; the power of dominating situations; it is saying, the power of the position; the power of knowledge before my staff and my patients.

It is having knowledge, showing respect, confidence when making decisions, and credibility from subalterns; having strong influence over colleagues; it is occasional use.

The power of the responsibility of believing in people; the knowledge, the desire to constantly improve, of sharing with people every day; to help people who study to resolve situations; to help my colleagues reach goals they though impossible.

It is the power of the position; following the organization's rules; responsibility regarding institutional norms; constancy; the desire of overcoming; and I am a visionary 
Results show the phenomena revealed in this study by the two categories, power and power of humane care, which include the components of love. - The nurses' perspectives regarding power imply making decisions and solving problems, and are associated with authority, communication abilities, influence, dominium and dependence, which demands capacity. Interaction with the informants permitted observing the nurses' rejection to speak about power, and the confusion between the term and activities that require power. Other informants clearly identified that only power makes it possible for high administrative positions to exist; and in a very subtle way, others associate power with influence. This is understood as a reflex that Venezuelan nursing remains attached to the old paradigm of values, which is characterized by protection behaviors to ensure safety, in line with the organization's norms and requirements. This is related to the fact that Venezuelan nursing appeared in 1930, in sheer modern times, with mechanistic organizational models, in schools as well as in hospitals. Nurses show behaviors specific to this model, which continue after 70 years.

- Regarding the perspectives of humane care power, nurse informants associate power with the job position, but not with the care they provide. Only three of the nine nurses timidly associated power with the service provided to others. It is believed that, innocently, nurse practitioners identify the technical dimension involved in health care and, at a lower level, the affective, ethical and esthetical dimension, but dissociated from the knowledge they have regarding the immense power that emanates from practicing humane care.

- Patients describe nurses as being rushed and in a bad mood. This is interpreted as nursing continuing to be based on the technical-scientific paradigm, since that is how it appeared in Venezuela.

- Patients expect nurses to be loveable, thoughtful, caring, to follow treatments at the established time, and to be sympathetic, considerate and understanding toward them. They hope to see a humane nurse, but they find that person very technical. This is interpreted as a product of three relevant factors. One factor is that health institutions privilege technical skills. Another fact could be that the health system remains anchored in the bureaucratic model, in which procedure abilities prevail and favor impersonality, thus moving affective, emotional or spiritual actions to the background. Hence, it disagrees with the new view of the world, which is focused on humans and requires nurses to provide eminently humanistic care. The third fact is that management at health facilities likely remains directed toward an administration that seeks quantitative production, performing tasks and controlling people.

- The researcher's perspectives regarding power and the power of humane care are products of the systematic study of those issues, in which love is the intersubjective expression that surpasses all others.

\section{THE THEORETICAL STRUCTURE OF LOVING HUMANE CARE POWER}

Structural elements consist of loving humane care and power, and the functional elements are the nurse, the healthy or ill person, the environment and nursing. These items are described in tables 3 and 4.

- loving humane care is understood as an intersubjective relationship between nurses and healthy or ill people, in which love is given and taken: concern and interest, respect, understanding and responsibility, in a reciprocal way.

- Nurse practitioners are those interested in the health, well being and lives of healthy or ill people. They respect, understand and take responsibility for their patients' health care.

- Healthy or ill people are those who receive health care from nurses and are encouraged to live again, become interested in their recovery, and have new dreams, strength and illusions.

- The environment is the physical setting where health care is offered, characterized by coziness, flexibility, participation and sensitivity.

- Nursing consists of a strong, united, cohesive team, centered on humane care and with a clear positive social image.

- Power is the social strength, product of the intersubjective relationship between nurses - health or ill individuals, groups or communities. 
Table 3 - Loving humane care, with an intersubjective relationship between nurses and healthy or ill people

\begin{tabular}{|c|c|c|}
\hline \multicolumn{3}{|c|}{ Loving Humane Care } \\
\hline $\begin{array}{l}\text { Gives and gets love, provides safety, respect toward others, } \\
\text { communication, and exerts influence }\end{array}$ & \multicolumn{2}{|c|}{$\begin{array}{c}\text { Shows interest in people, meets their needs, understands others } \\
\text { experience }\end{array}$} \\
\hline \multicolumn{2}{|c|}{ Nurse } & Healthy Or III People \\
\hline \multicolumn{2}{|c|}{ - Shows interest in others' life and wellbeing. } & - Is encouraged to live again \\
\hline - Respec & \multicolumn{2}{|c|}{ - Has a will to recover } \\
\hline - Understands others' pain and lister & \multicolumn{2}{|c|}{ - Arouses the longing to live } \\
\hline - Provides c & \multicolumn{2}{|c|}{ - Feels born again } \\
\hline - Cares V & \multicolumn{2}{|c|}{ - Has new dreams, strengths and illusions } \\
\hline Envvironment & & Nursing \\
\hline - Cozy & trength & - Strong \\
\hline - Flexible & relationship & - United \\
\hline \multicolumn{2}{|l|}{ - Participative } & - Cohesive \\
\hline \multirow[t]{2}{*}{ - Autonomous } & & - Centered \\
\hline & \multicolumn{2}{|c|}{ - Positive social image } \\
\hline
\end{tabular}

Table 4 - Power as social strength, a product of the intersubjective relationship between nurses and healthy or ill people

\begin{tabular}{|c|c|}
\hline \multicolumn{2}{|c|}{ Power - Social strength, intersubjective relationship } \\
\hline Nurse & Healthy or ill people \\
\hline - Shows interest in others' life and wellbeing & - Are encouraged to live again \\
\hline - Respects human dignity & - Have the will to recover \\
\hline - Understands others' pain and listens to their apprehensions, fears, and anguish & - Arouse the longing to live \\
\hline - Provides comfort and support & - Feel born again \\
\hline - Cares with responsibility & - Have new dreams, strengths and illusions \\
\hline Envvironment & Nursing \\
\hline - Cozy & Strong \\
\hline - Flexible & United \\
\hline - Participative & Cohesive \\
\hline \multirow[t]{2}{*}{ - Autonomous } & Centered \\
\hline & Positive social image \\
\hline $\begin{array}{l}\text { Gives and gets love, provides safety, respect toward others, communication, } \\
\text { and exerts influence }\end{array}$ & $\begin{array}{l}\text {, Show interest in people, meet their needs, understand others' } \\
\text { experience }\end{array}$ \\
\hline
\end{tabular}

Hence, this study presented the conception of loving humane care as an intersubjective relationship between nurses and healthy or ill people. The love exchanged in these relationships is understood as the ability to demonstrate concern and interests, respect dignity, take responsibility for health care and understand the implied health situation.

Therefore, the theoretical structure of loving humane care consists of: concern and interest, understanding, responsibility and respect for dignity. This permits for redirecting nurses' work as a possible work technology, as shown below:

- concern and interest are addressed through permanent face-to-face authentic conversation with patients;

- respect for dignity in professional autonomous work, patients' freedom to make or participate in decisions affecting them, as well as having their rights respected, provides them with individualized health care;

- comprehension through empathy, as a feeling that is expressed by putting yourself in the place of patients, not guessing but exploring what they feel regarding their health situation;

- the other element is the responsibility understood from the perspective of the moral commitment to respond for the consequences of the interventions offered as caregivers and the obligation to complete the activities and tasks determined by the job position.

The theoretical structure elements of loving humane care include Caring Nursing, which presumes health care with concern, respect, comprehension and responsibility, until it is passed to patients. These healthy or ill people should have become interested in and concerned about recovering or improving their health, to the point that they feel the desire to live and create new illusions. The environment should be cozy, welcoming, ventilated, illuminated, comfortable and harmonically decorated (art, music, nature).

This gives new directions to the attitude of loving caring nurses, which involves the stages of receiving patients (which cannot be delegated); the recommendations and trust required for loving 
humane care; following the health care process according to patients' needs and conditions; and, giving final instructions when the care period is over and make them comfortable until the next time you meet.

It is concluded that the theoretical structure of loving humane care is directed to emphasizing the beauty, deepness and complexity of the nursing profession and lead it to transcendence through love.

\section{SOME FINAL CONSIDERATIONS}

- the theoretical structure of loving humane care could lead to a powerful nursing in this historical moment;
- practicing power and humane care in nursing is founded on the technical-scientific paradigm of modern times.;

- there is disagreement between the nurses', patients' and researcher's perceptions regarding power and humane care;

- the nature and sources of power and its advantages to nursing remain unknown;

- spaces for discussion should be created to address the meaning of power, the power of humane care and the power of loving humane care;

- practicing humane care power could be a determinant for the social legitimacy of nursing in Venezuela.

\section{REFERENCES}

1.Gómez RG. Metodología de la investigación cualitativa. Málaga: Ediciones Alibe; 1996.

2. Giddens A. Sociología. Madrid: Alianza Editorial; 2000.

3. Neira E. El saber del poder. Introducción de ciencias políticas. Mérida: ULA; 1991.

4. Parker FM. Prophet of Management. Boston: Harvard Business School Press; 1994

5. Larrañaga I. Sube conmigo. Perú: Ediciones Paulinas; 1998.

6. Gevaert J El problema del hombre. Introducción a la antropología filosófica. Salamanca: Ediciones Sígueme; 1993. 7. Buscaglia L. El Amor: la experiencia más importante en la vida. Colombia: Editorial Diana; 1985.

8. Paterson J, Zderad L. Humanistis Nursing. United States of America: National League for Nursing; 1988.

9. Ruiz J. La descodificación de la vida cotidiana: métodos de investigación cualitativa. Bilbao: Universidad de Deusto; 1989.

10. Husserl E. Ideas: relativas o una fenomenológica para y una filosofía fenomenológica. España: Editorial Fondo de Cultura Económica; 1993.

11. Merton R. Teoría y estructuras sociales. México: Editorial Fondo de Cultura Económica; 1992. 